\title{
ISOTOPE CORRELATION STUDIES RELATIVE \\ TO HIGH ENRICHMENT TEST REACTOR FUELS
}

\author{
W. J. Maeck \\ R. L. Tromp \\ F. A. Duce \\ W. A. Eme 1
}

ALLIED CHEMICAL CORPORATION

IDAHO CHEMICAL PROGRAMS - OPERATIONS OFFICE

\section{? ? ?}

PUELE

Laves Nolliam

Authorizing Official

Date: $12 / 22 / 2005$
Date Published - June 1978

Prepared for the

Energy Research \& Development Administration Under Contract No. EY-76-C-07-7540 


\section{DISCLAIMER}

This report was prepared as an account of work sponsored by an agency of the United States Government. Neither the United States Government nor any agency Thereof, nor any of their employees, makes any warranty, express or implied, or assumes any legal liability or responsibility for the accuracy, completeness, or usefulness of any information, apparatus, product, or process disclosed, or represents that its use would not infringe privately owned rights. Reference herein to any specific commercial product, process, or service by trade name, trademark, manufacturer, or otherwise does not necessarily constitute or imply its endorsement, recommendation, or favoring by the United States Government or any agency thereof. The views and opinions of authors expressed herein do not necessarily state or reflect those of the United States Government or any agency thereof. 


\section{DISCLAIMER}

Portions of this document may be illegible in electronic image products. Images are produced from the best available original document. 


\section{ABSTRACT}

Several correlations of fission product isotopic ratios with atom percent fission and neutron flux, for highly enriched $235 \mathrm{U}$ fuel irradiated in two different water moderated thermal reactors, have been evaluated. In general, excellent correlations were indicated for samples irradiated in the same neutron spectrum; however, significant differences in the correlations were noted with the change in neutron spectrum. For highly enriched $235 \mathrm{U}$ fuel, the correlation of the isotopic ratio $143 \mathrm{Nd} / 145+146 \mathrm{Nd}$ with atom percent fission has wider applicability than the other fission product isotopic ratio evaluated. The ${ }^{137} \mathrm{Cs} / 135 \mathrm{Cs}$ atom ratio shows promise for correlation with neutron flux. Correlations involving heavy element ratios are very sensitive to the neutron spectrum. 
CONTENTS

Page

ABSTRACT. i i

1. INTRODUCTION.................................... 1

2. SAMPLE DESCRIPTION, HISTORY, AND ANALYSIS.............. I

3. FISSION PRODUCT ISOTOPE CORRELATIONS WITH ATOM PERCENT FISSION............................. 4

$3.1{ }^{132} \mathrm{Xe} /{ }^{131} \mathrm{Xe}$ Correlation with a/oF................. 4

$3.2{ }^{84} \mathrm{Kr} /{ }^{8}{ }^{3} \mathrm{Kr}$ Correlation with $\mathrm{a} / \mathrm{OF} \ldots \ldots \ldots \ldots \ldots \ldots .6 .6 .6$

3.3 Cesium Isotope Ratio Correlations with a/oF......... 6

3.4 Neodymium Isotope Ratio Correlations with a/oF....... 7

4. FISSION PRODUCT ISOTOPE CORRELATIONS WITH

NEUTRON FLUX................................... 12

5. HEAVY ELEMENT CORRELATIONS......................... 15

6. SUMMARY AND CONCLUSIONS........................... 18

REFERENCES.................................... 20

TABLES

I. REACTOR DATA FOR SAMPLES USED IN CORRELATION STUDIES....... 3

II. SUMMARY OF ISOTOPE CORRELATIONS FOR HIGHLY ENRICHED $235 \mathrm{U}$ FUEL..................................

FIGURES

1. Correlation of ${ }^{132} \mathrm{Xe} /{ }^{131} \mathrm{Xe}$ Atom Ratio With Atom Percent Fission................................. 5

2. Correlation of ${ }^{84} \mathrm{Kr} /{ }^{83} \mathrm{Kr}$ Atom Ratio With Atom Percent Fission.................................. 5

3. Correlation of ${ }^{134} \mathrm{Cs} /{ }^{133} \mathrm{Cs}$ Atom Ratio With Atom Percent Fission................................. 8

4. Correlation of ${ }^{134} \mathrm{Cs} /{ }^{137} \mathrm{Cs}$ Atom Ratio With Atom Percent Fission. 
5. Correlation of $143 \mathrm{Nd} / 145+146 \mathrm{Nd}$ Atom Ratio With Atom Percent Fission............................. 10

6. Correlation of $146 \mathrm{Nd} /{ }^{145} \mathrm{Nd}$ Atom Ratio With Atom Percent Fission........................... 10

7. Correlation of Neodymium Isotope Ratios With Atom Percent Fission............................. 11

8. Nuclide Mass Region $733-137 \ldots \ldots \ldots \ldots \ldots \ldots \ldots \ldots \ldots \ldots$

9. Correlation of ${ }^{136} \mathrm{Xe} /{ }^{134} \mathrm{Xe}$ Atom Ratio With Neutron Flux................................. 13

10. Correlation of ${ }^{137} \mathrm{Cs} /{ }^{135} \mathrm{Cs}$ Atom Ratio With Neutron Flux................................ 13

11. Correlation of $148 \mathrm{Nd} / 145+146 \mathrm{Nd}$ Atom Ratio With

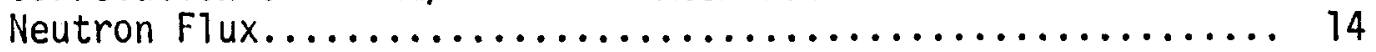

12. Isotopic Composition of Plutonium Produced in the Irradiation of $93 \%$ Enriched $235 \mathrm{U} \ldots \ldots \ldots \ldots \ldots \ldots . \ldots 16$

13. Correlation of a/o $238 \mathrm{pu}$ with $a / 0236 \mathrm{U} \ldots \ldots \ldots \ldots \ldots \ldots$

14. Correlation of Pu/U Atom Ratio with a/o $236 \mathrm{U} \ldots . . . \ldots \ldots . . .17$ 


\section{INTRODUCTION}

The concept using certain selected fission product isotopic ratios to estimate burnup was first proposed by this laboratory in 1965.1 This original concept was based only on theoretical calculations with little supporting experimental data. Early in the 1970's when experimental data for power reactor fuels from the European communities became available, it became apparent that many unique correlations of both fission products and heavy elements could be used to provide information to verify fuel analyses and to deduce certain parameters relative to reactor operations. A symposium sponsored by the European Safeguards and Research and Development Association in Rome, March, $1974^{2}$ concluded that isotope correlation techniques, ICT, may have value in the safeguarding and management of special nuclear materials, but that a considerable amount of additional experimental data were needed to fully evaluate ICT. Since that time, the bulk of the new data and the data base which have been generated has been for light water power reactor fuels. Little information exists for highly enriched fuels (i.e., $>90 \% 235 \mathrm{U}$ ) of the type used in material test reactors and military reactors.

This paper evaluates various isotope correlations with potential application to highiy enriched fuels, gives information which can be used in formulating an isotope correlation data base for highly enriched fuels, and identifies certain problems which must be considered in the application of ICT. Data for a wide range of burnup for highly enriched $235 \mathrm{U}$ fuel for two different reactors are given.

\section{SAMPLE DESCRIPTION, HISTORY, AND ANALYSIS}

Two independent groups of samples from two different reactors were analyzed for selected fission products and heavy elements. The first group consisted of 14 sample punchings, $(20.6 \mathrm{~cm}$ dia.) seven each from two different experimental U-Al fuel plates (93\% 235U) irradiated in the Advanced Test Reactor, ATR, located at the Idaho National Engineering Laboratory, INEL. For these samples, the atom percent fission, 
a/oF, (fissions per initial total heavy element atoms) ranged from 13-51\%. Both fuel plates experienced the same irradiation history, 2100 days of full reactor power during a period of 335 days.

The second group was comprised of six aluminum capsules containing $>99 \% 235 \mathrm{U}$ as $\mathrm{U}_{3} \mathrm{O}_{8}$, irradiated in the Engineering Test Reactor, ETR, for the purpose of measuring absolute thermal fission yields. Three of these samples were irradiated to $\sim 1 \mathrm{a} / \mathrm{oF}$, and three to $\sim 40 \mathrm{a} / \mathrm{oF}$. The ETR reactor is also located at the INEL. The three low a/oF samples were irradiated for 20 consecutive days. The three high a/of samples resided in the reactor 320 days, during which time the reactor was operating 185 days in a cyclic manner.

The neutron flux, measured $a / O F$, and the capture-to-fission ratio for $235 \mathrm{U}, \alpha_{235}$, for each sample are given in Table I. Also given, is the location of each sample punched from the ATR fuel plates. Of particular significance is that the neutron spectrum associated with the ATR fuel plates samples was much harder than that for the ETR samples. For the ATR samples, $\alpha_{235}$ was $\sim 0.215$ and essentially constant for all samples, while for the ETR samples, the average value for $\alpha_{235}$ was 0.183 .

Each sample was mass spectrometrically analyzed for the following: 1) krypton isotopic abundance, 2) xenon isotopic abundance, 3) cesium isotopic abundance and concentration, 4) neodymium isotopic abundance and concentration, 5) uranium isotopic abundance and concentration, and 6) plutonium isotopic abundance and concentration. The 14 samples from the ATR fuel plates represent the nearly ideal case for isotope correlation studies because all of the samples have the same irradiation history and a wide range of a/oF is covered. 
TABLE I. REACTOR DATA FOR SAMPLES USED IN CORRELATION STUDIES

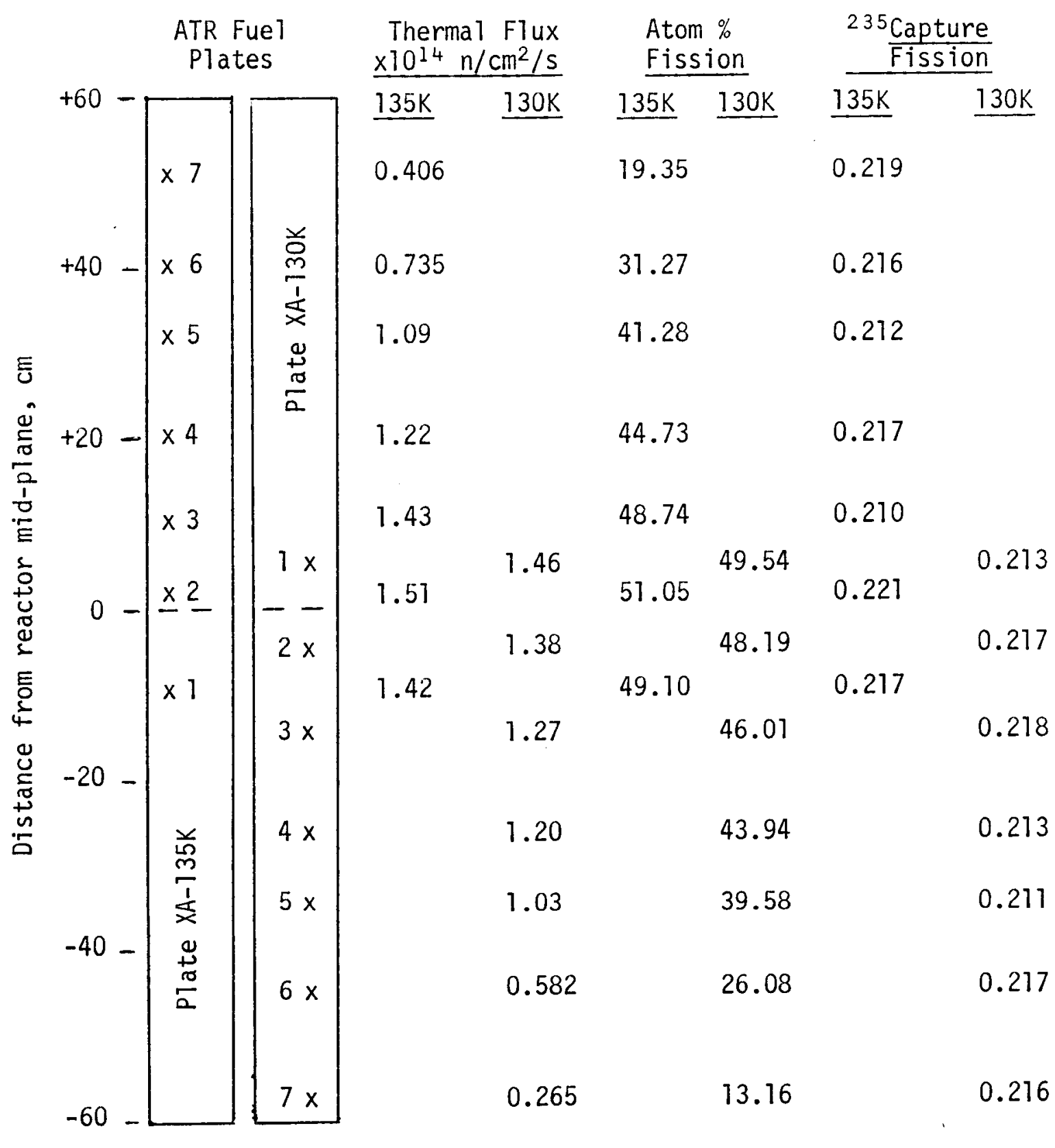

ETR Samples

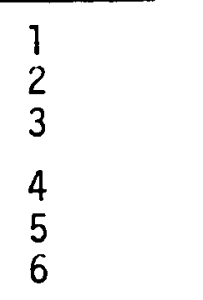

0.61
0.50
0.62
0.076
0.12
0.065

39.74

34.52

0.183

0.183

39.89

0.179

0.722

1.186

$20.18^{\mathrm{a}}$

20.18

$\sim 0.18$

${ }^{a}$ Estimated value. 


\section{FISSION PRODUCT ISOTOPE CORRELATIONS WITH ATOM PERCENT FISSION}

Fission product isotope correlations with a/of for highly enriched $235 \mathrm{U}$ fuel are given for ${ }^{84} \mathrm{Kr} /{ }^{83} \mathrm{Kr},{ }^{132} \mathrm{Xe} /{ }^{131} \mathrm{Xe},{ }^{134} \mathrm{Cs} /{ }^{133} \mathrm{Cs},{ }^{134} \mathrm{Cs} /{ }^{137} \mathrm{Cs}$, ${ }^{146} \mathrm{Nd} / 145 \mathrm{Nd}$, and $1{ }^{143} \mathrm{Nd} / 145^{+} 146 \mathrm{Nd}$. For many of these correlations, the effect of the neutron spectrum is significant, especially when the neutron capturing nuclide has a large resonance integral cross section, $\mathrm{RI}$, compared to the thermal neutron capture cross section value. In this report, the thermal capture cross section and RI values are taken from BNL $-325^{3}$.

\section{$3.1 \quad 132 \mathrm{Xe} / 131 \mathrm{Xe}$ Correlation with a/oF}

The change in the ${ }^{132} \mathrm{Xe} /{ }^{131} \mathrm{Xe}$ isotope ratio with a/oF was one of the first isotope correlations proposed. ${ }^{1}$ Because the isotopic composition of the fission gases released during the dissolution of large batches of irradiated fuel is essentially constant throughout the dissolution, sampling and on-line analysis of the dissolver off-gas has been suggested as a means for obtaining burnup information and the heavy isotope content of the fuel. ${ }^{4}$ Koch and Bresesti ${ }^{4}$ have shown the correlation of ${ }^{132} \mathrm{Xe} /{ }^{131} \mathrm{Xe}$ with $\mathrm{a} / \mathrm{oF}$ for six different reactor fuels, representing both pressurized and boiling water reactors. For these data, the indicated $\mathrm{a} / \mathrm{OF}$ for a given ${ }^{132} \mathrm{Xe} /{ }^{131} \mathrm{Xe}$ ratio varies as much as $35 \%$. This is believed due to variation in the neutron spectrum as discussed below.

The correlation of the ${ }^{132} \mathrm{Xe} /{ }^{131} \mathrm{Xe}$ isotope ratio as a function of a/oF for highly enriched $235 \mathrm{U}$ fuel is shown in Figure 1. These data show good correlation for a given neutron spectrum but significant differences between neutron spectra. For a ${ }^{132} \mathrm{Xe} /{ }^{131} \mathrm{Xe}$ ratio of 1.65 , the indicated a/oF values range from $19 \mathrm{a} / \mathrm{oF}$ for the ATR samples to $36 \mathrm{a} / \mathrm{OF}$ for the ETR samples. This effect is solely due to the large ${ }^{131} \mathrm{Xe}$ RI capture cross section ( $\left.870 \mathrm{~b}\right)$ which is nearly 10 times larger than the thermal neutron capture cross section (90 b). 


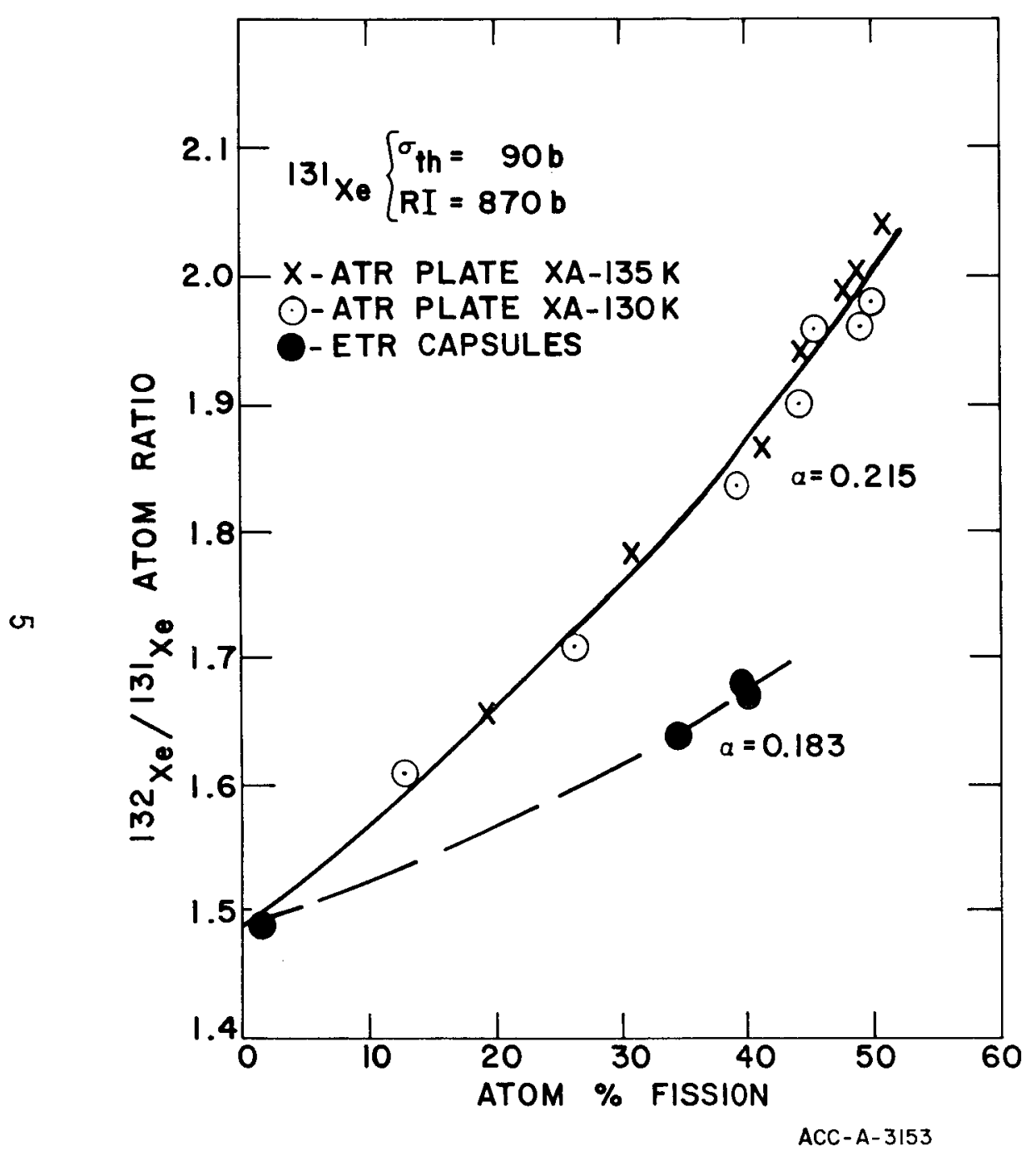

Fig. 1 Correlation of $132 \mathrm{Xe} /{ }^{131} \mathrm{Xe}$ Atom Ratio with Atom Percent Fission

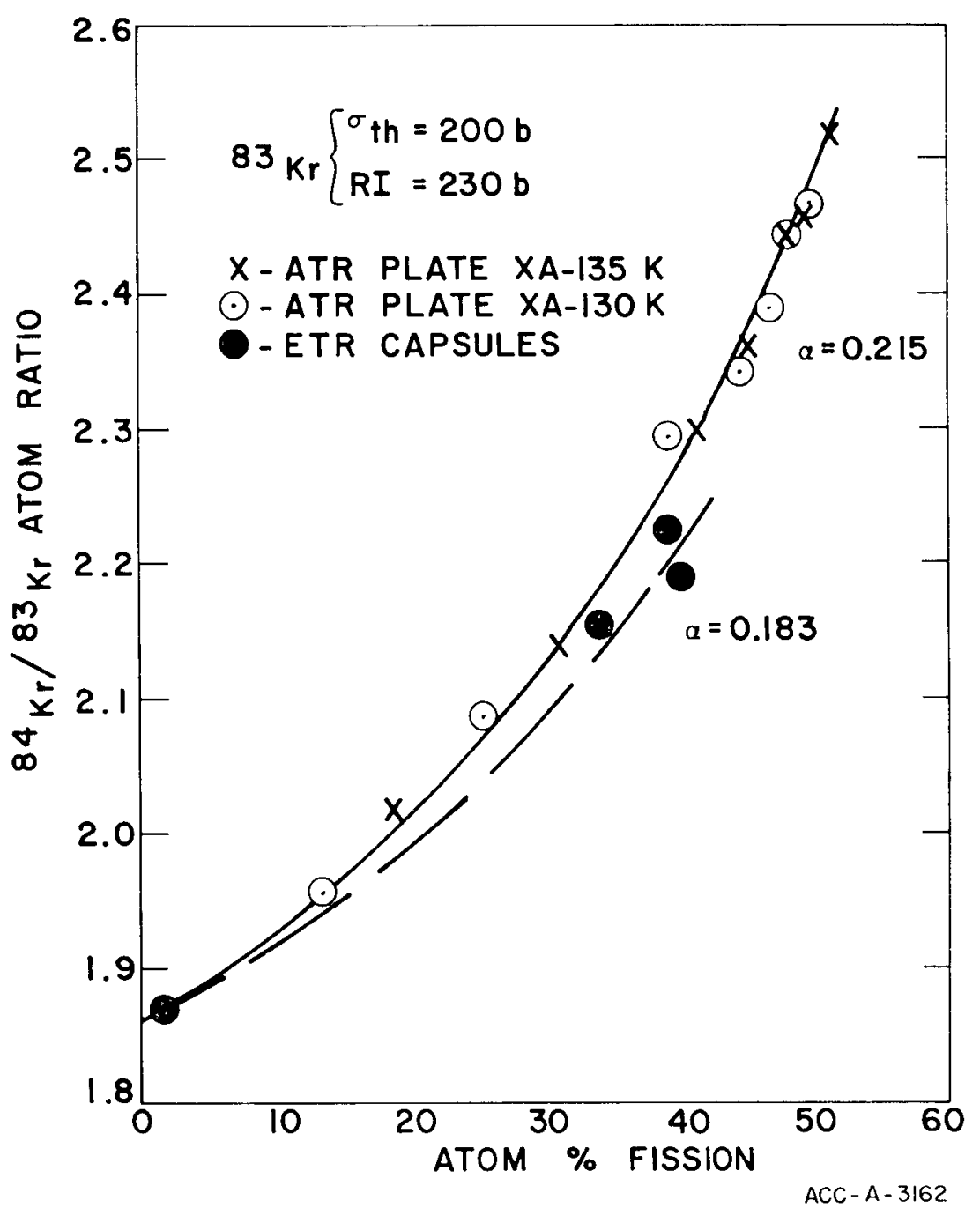

Fig. 2 Correlation of ${ }^{84} \mathrm{Kr} /{ }^{83} \mathrm{Kr}$ Atom Ratio with Atom Percent Fission 
Based on the data given in Figure 1 , it is suggested that the use of ${ }^{132} \mathrm{Xe} /{ }^{131} \mathrm{Xe}$ isotope ratio to estimate a/oF be reevaluated.

\section{$3.284 \mathrm{Kr} /{ }^{83} \mathrm{Kr}$ Correlation with a/oF}

The change in the ${ }^{84} \mathrm{Kr} /{ }^{83} \mathrm{Kr}$ isotope ratio with a/oF, like that for ${ }^{132} \mathrm{Xe} /{ }^{131} \mathrm{Xe}$, has long been recognized. Ariemma et $a 1^{4}$ have shown reasonable correlations for ${ }^{84} \mathrm{Kr} /{ }^{83} \mathrm{Kr}$ isotope ratio as a function of uranium depletion for Garigliano power reactor fuel. The correlation of the ${ }^{84} \mathrm{Kr} /{ }^{83} \mathrm{Kr}$ isotope ratio with a/oF for highly enriched ${ }^{235} \mathrm{U}$ fuel is given in Figure 2. Excellent correlation is shown for the ATR fuel samples over the range of 13-51 a/oF; however, a different correlation is shown for the ETR samples. The difference, however, is considerably less than that for the ${ }^{132} \mathrm{Xe} /{ }^{131} \mathrm{Xe}$ ratio because the ratio of the $\mathrm{RI}$ capture cross section for ${ }^{83} \mathrm{Kr}$ to the thermal neutron capture cross section is much smaller than for 131 Xe.

For fully enriched ${ }^{235} \mathrm{U}$ fuel, the correlation of the ${ }^{84} \mathrm{Kr} /{ }^{83} \mathrm{Kr}$ ratio with a/0 fission is preferred to the ${ }^{132} \mathrm{Xe} /{ }^{131} \mathrm{Xe}$ ratio, because the effect of the neutron spectrum is less, and the sensitivity of the ratio (\% change in the ${ }^{84} \mathrm{Kr} /{ }^{83} \mathrm{Kr}$ ratio with a/oF) is greater.

\subsection{Cesium Isotope Ratio Correlations with a/oF}

The production of the shielded isotope, ${ }^{134} \mathrm{Cs}$, by neutron capture on ${ }^{133} \mathrm{Cs}$ has long been recognized as an indicator of neutron fluence, and hence, $\mathrm{a} / \mathrm{oF}$. The ratio, ${ }^{134} \mathrm{Cs} /{ }^{137} \mathrm{Cs}$, has received more attention in isotope correlation studies than the other cesium isotopes because both are radioactive and can be measured using conventional counting techniques. Several correlations of the ${ }^{134} \mathrm{Cs} /{ }^{137} \mathrm{Cs}$ ratio with various fuel parameters, such as, $a / \mathrm{OF}^{4}, 240 \mathrm{Pu}$ production ${ }^{4}$, and plutonium/uranium mass ratios 6,7 , have been reported. 
To more fully explore other isotope correlations involving the cesium isotopes, all of the samples identified in our work were analyzed using mass spectrometry. In all cases, the measured atoms of the radioactive isotopes were in-pile and out-pile decay corrected. The correlation of the ${ }^{134} \mathrm{Cs} /{ }^{133} \mathrm{Cs}$ atom ratio with a/oF for highly enriched $235 \mathrm{U}$ fuel is shown in Figure 3. The correlation within a given group of samples is excellent but a significant difference exists between the ATR and ETR samples (Figure 3). Again, this is the result of the harder ATR neutron spectrum, and the large RI capture cross section for ${ }^{133} \mathrm{Cs}$ (415 b) compared to the thermal neutron capture cross section $(29 \mathrm{~b})$. For a measured ${ }^{134} \mathrm{Cs} /{ }^{133} \mathrm{Cs}$ atom ratio of 0.025 , the indicated a/oF values range from $20 \mathrm{a} / \mathrm{oF}$ for an ATR sample to $38 \mathrm{a} / \mathrm{oF}$ for an ETR sample. This comparison clearly shows the effect of the neutron spectrum on the production of ${ }^{134} \mathrm{Cs}$ from ${ }^{133} \mathrm{Cs}$.

The sensitivity of ${ }^{134} \mathrm{Cs}$ production to the neutron spectrum is also shown for the correlation of ${ }^{134} \mathrm{Cs} /{ }^{137} \mathrm{Cs}$ atom ratio with a/oF (Figure 4)。 Because of this sensitivity to neutron spectra, caution must be exercised in the use of ${ }^{134} \mathrm{Cs}$ for isotope correlation studies.

\subsection{Neodymium Isotope Ratio Correlations with a/oF}

Few correlation studies involving neodymium isotopes have been reported, in spite of the fact that ${ }^{148} \mathrm{Nd}$ is commonly measured to calculate a/oF. Based on the neodymium isotopic data generated in this current study, we believe more information can be extracted from the neodymium data than from correlations involving other fission products.

The most important neodymium correlation is that for the atom ratio of $143 \mathrm{Nd} / 145+146 \mathrm{Nd}$ with a/oF. The use of the sum of $145 \mathrm{Nd}+146 \mathrm{Nd}$ is preferred to ${ }^{144} \mathrm{Nd}$ because information relative to the decay of ${ }^{144} \mathrm{Ce}$ is not required. In addition, al though the ratio of $145 \mathrm{Nd} /{ }^{146} \mathrm{Nd}$ is variable with a/oF, the sum of $145 \mathrm{Nd}+146 \mathrm{Nd}$ isotopic fraction to total neodymium is constant for all levels of a/oF in highly enriched fuel. The correlation of $143 \mathrm{Nd} / 1^{145+146} \mathrm{Nd}$ with a/OF for highly enriched 


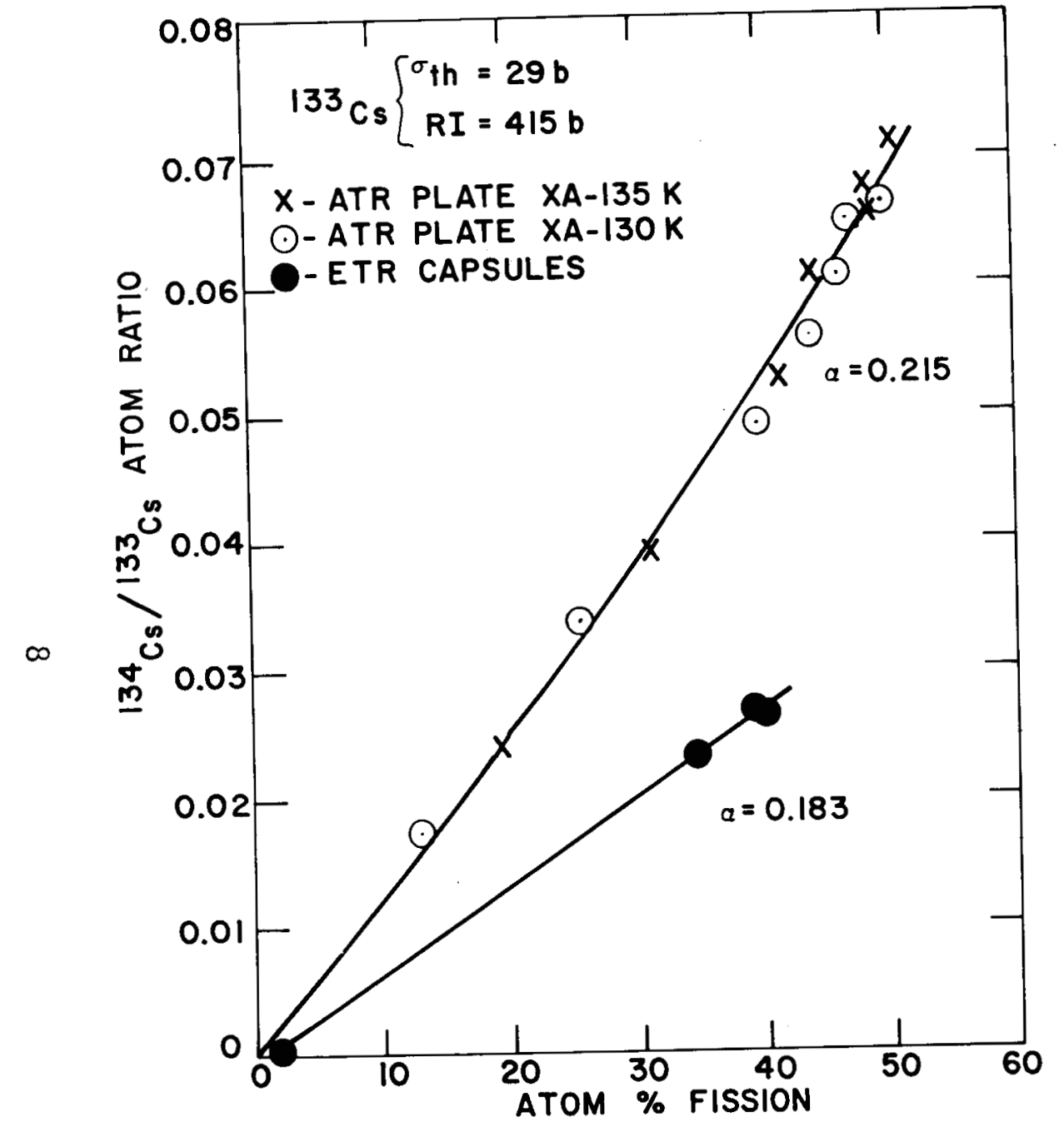

Fig. 3 Correlation of $1{ }^{34} \mathrm{Cs} /{ }^{133} \mathrm{Cs}$ Atom Ratio with Atom Percent Fission

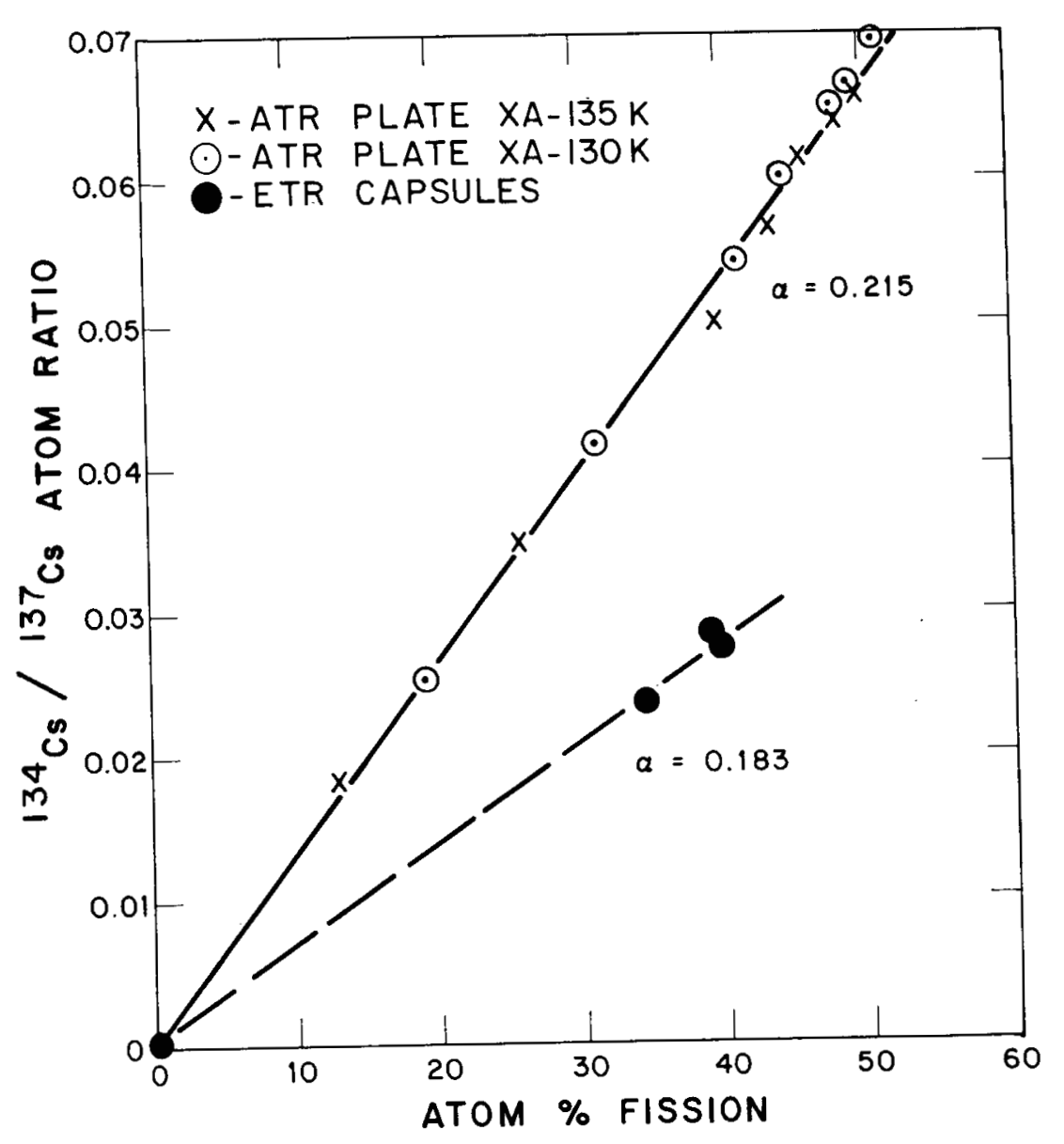

Fig. 4 Correlation of $1{ }^{134} \mathrm{Cs} /{ }^{137} \mathrm{Cs}$ Atom Ratio with Atom Percent Fission 
$235 \mathrm{U}$ fuel is shown in Figure 5. Of particular importance is the absence of a significant neutron spectrum effect as indicated by the same correlation for the ATR and ETR data. This is a result of a small RI capture cross section for ${ }^{143} \mathrm{Nd}(\sim 740 \mathrm{~b})$ compared to the thermal neutron capture cross section (325 b). Thus, the correlation of $143 \mathrm{Nd} /{ }^{145+146} \mathrm{Nd}$ has wider applicability than any of the other correlations previously discussed. From the data given in Figure 5 , it should be possible to determine the a/oF for highly enriched $235 \mathrm{U}$ fuels to within a few percent based only on the isotopic composition of neodymium. No absolute measurement of the number of atoms of a specific isotope is required.

A second important neodymium isotope correlation is that of the isotopic ratio of $146 \mathrm{Nd} /{ }^{145} \mathrm{Nd}$ with a/oF. For this case, a significant spectrum effect is noted (Figure 6 ).

Thus, for highly enriched $235 \mathrm{U}$ fuels, the isotopic composition of fission product neodymium can be used to estimate a/oF from the isotopic ratio of $143 \mathrm{Nd} / 145^{+} 146 \mathrm{Nd}$, and having established a value for a/oF, $\alpha_{235}$ (neutron spectrum) can be deduced from the ${ }^{146} \mathrm{Nd} /{ }^{145} \mathrm{Nd}$ isotope ratio. Figure 7 , a combination of Figures 5 and 6 , gives the correlation of $146 \mathrm{Nd} /{ }^{145} \mathrm{Nd}$ and ${ }^{143} \mathrm{Nd} /{ }^{145+146} \mathrm{Nd}$ with a/oF for two different neutron spectra.

Because of the indicated usefulness of the neodymium isotopic data in isotope correlation studies relative to highiy enriched fuel, additional neodymium data which can be associated with known values for a/oF and the neutron spectrum should be obtained to expand and verify the data base.

It is impossible to leave the subject of neodymium without some mention of $148 \mathrm{Nd}$. Although ${ }^{148} \mathrm{Nd}$ has, for many years, been used as a standard fission monitor for the measurement of the number of fissions and $a / o F$, it has now been established that a large ( $2440 \mathrm{~b})$ neutron capture cross section associated with $11 \mathrm{~d}-147 \mathrm{Nd}$ can give rise to high biased values, especially when the sample has been exposed to a high neutron flux $\left(>5 \times 10^{13} \mathrm{n} / \mathrm{cm}^{2} / \mathrm{s}\right) .^{8}$ This is again substantiated in our current work and, in fact, it is shown that the isotopic ratio of ${ }^{148} \mathrm{Nd} /{ }^{145+146} \mathrm{Nd}$ can be correlated with neutron flux (see Section 4). 


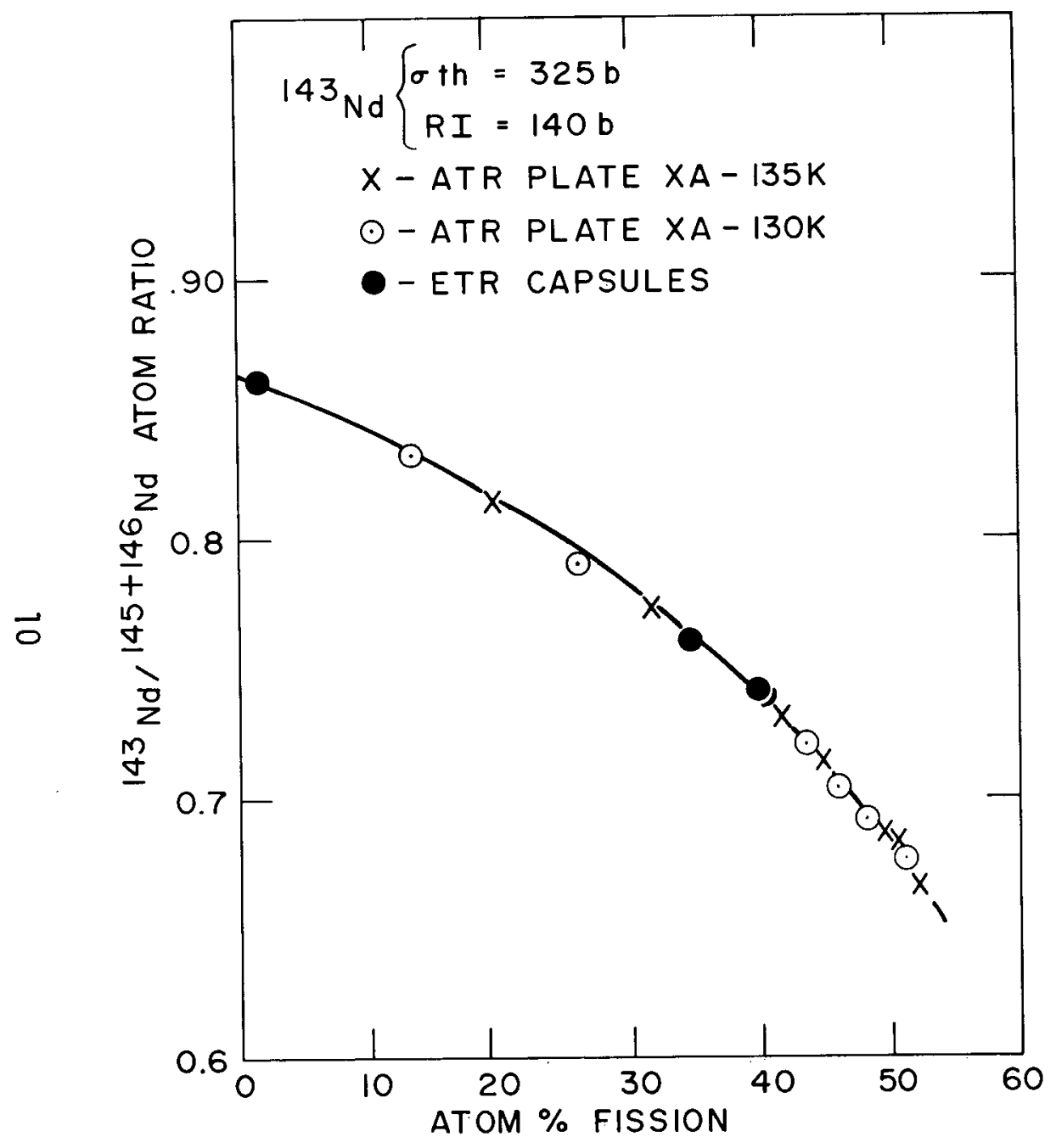

Fig. 5 Correlation of $14^{3} \mathrm{Nd} / 145+146 \mathrm{Nd}$ Atom Ratio with Atom Percent Fission

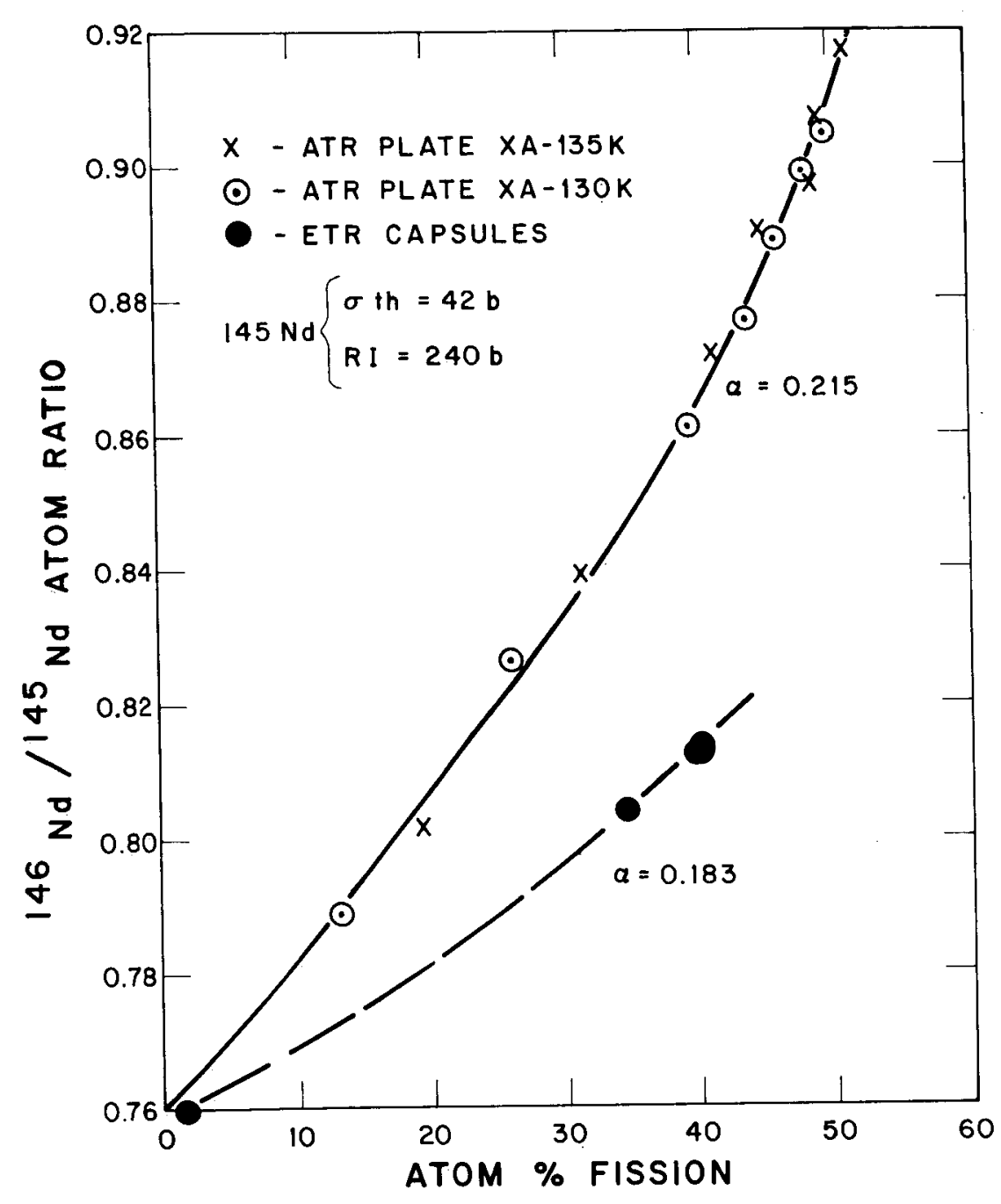

Fig. 6 Correlation of $146 \mathrm{Nd} / /^{145} \mathrm{Nd}$ Atom Ratio with Atom Percent Fission 


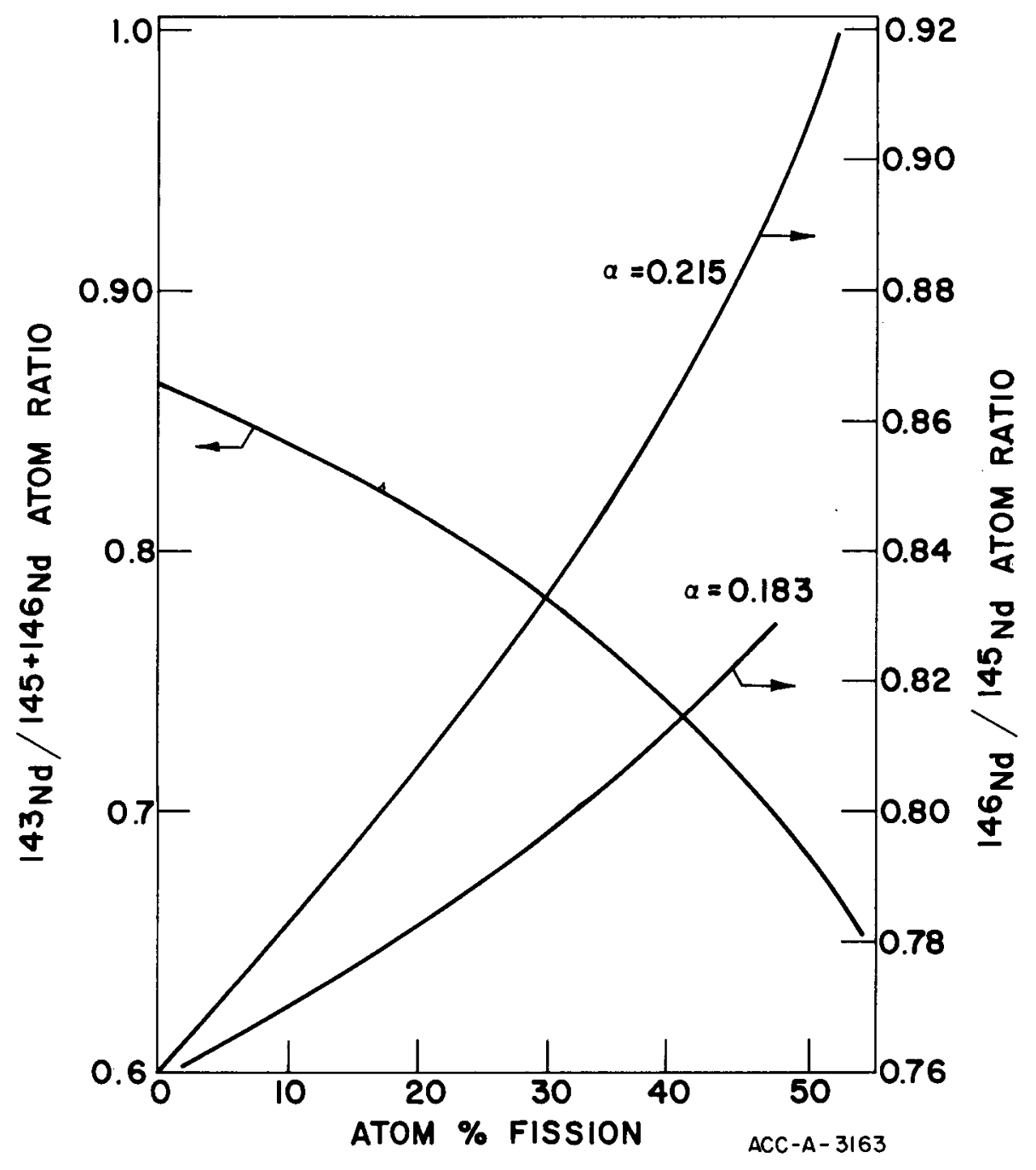

Fig. 7 Correlation of Neodymium Isotope Ratios with Atom Percent Fission

In our laboratory, the sum of $145 \mathrm{Nd}+146 \mathrm{Nd}$ is now the preferred monitor for the determination of the number of fissions and a/oF for highly enriched fuels. All of the values given in Table I for a/oF are based on the sum of ${ }^{145} \mathrm{Nd}$ and ${ }^{14.6} \mathrm{Nd}$. Use of ${ }^{148} \mathrm{Nd}$ gave values for the number of fissions which were biased high by $6-8 \%$ relative at the higher flux levels. 


\section{FISSION PRODUCT ISOTOPE CORRELATIONS WITH NEUTRON FLUX}

Certain fission product isotope ratios can be correlated with neutron flux if, there exists in one of the decay chains, a fission product with a short half-life and a high neutron capture cross section. For this case, transmutation of a nuclide in the A mass chain to the $A+1$ mass chain will be almost completely dependent upon the neutron flux. Two specific examples are, $9.17 \mathrm{~h}-135 \mathrm{Xe}$ with a $2,600,000 \mathrm{~b}$ thermal neutron capture cross section, and $11 \mathrm{~d}-147 \mathrm{Nd}$ with a thermal neutron capture cross section of $\sim 440$ b. Thus, competition between the decay mode and transmutation provides the basis for correlation with neutron flux.

For $9.17 \mathrm{~h}-135 \mathrm{Xe}$, two correlations with neutron flux are possible. The first is based on the atom ratio ${ }^{136} \mathrm{Xe} /{ }^{134} \mathrm{Xe}$ and the second on the ratio of ${ }^{137} \mathrm{Cs} /{ }^{135} \mathrm{Cs}$. This is the result of the short-lived ${ }^{135} \mathrm{Xe}$ either capturing a neutron to form stable ${ }^{136} \mathrm{Xe}$ or decaying to form $2.3 \times 10^{6} y-13^{5} \mathrm{Cs}$. The decay and transmutation scheme is shown in Figure 8. Because of the large neutron capture cross section $\left(2.6 \times 10^{6} \mathrm{~b}\right)$ for $9.17 \mathrm{~h}-135 \mathrm{Xe}$, the majority $(290 \%)$ of the $9.17 \mathrm{~h}-135 \mathrm{Xe}$ is transmuted to $136 \mathrm{Xe}$ in a typical power reactor or test reactor neutron flux. In the ${ }^{136} \mathrm{Xe} /{ }^{134} \mathrm{Xe}$ and the ${ }^{137} \mathrm{Cs} /{ }^{135} \mathrm{Cs}$ ratios, the amount of $134 \mathrm{Xe}$ and ${ }^{137} \mathrm{Cs}$ formed is directly proportional to a/oF, and is not subject to variations in neutron spectra.

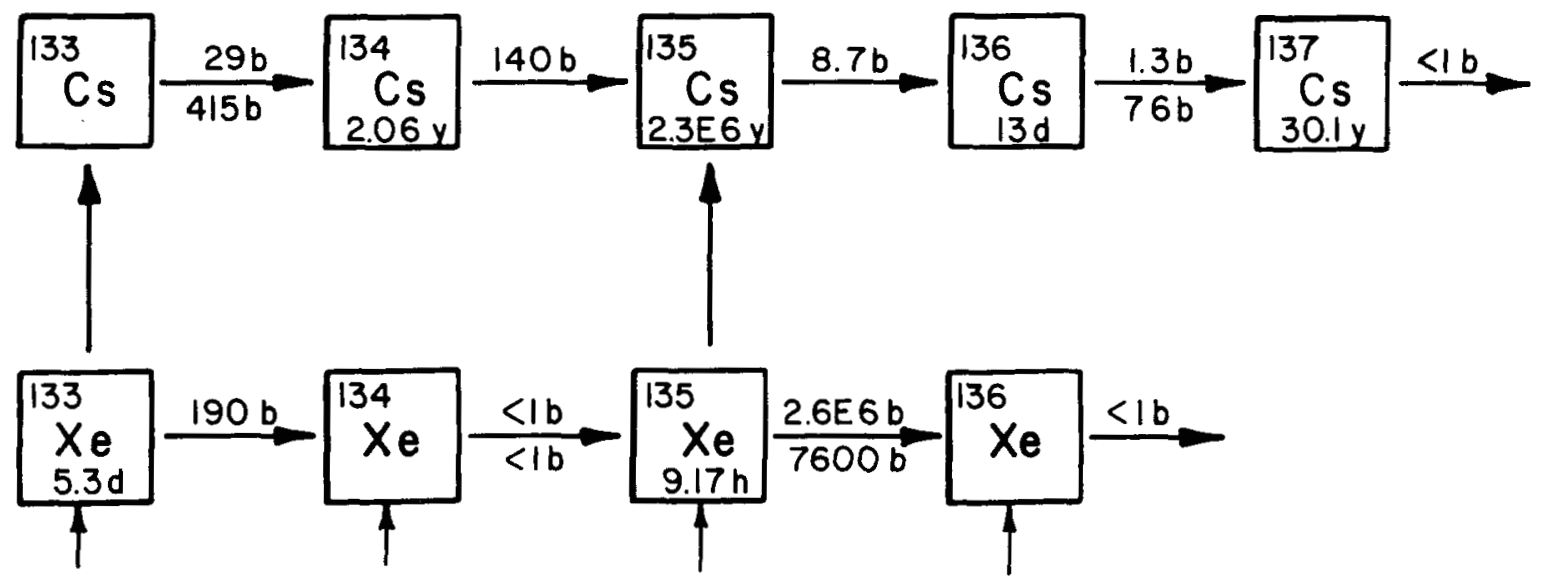

KEY $\underset{R I}{\sigma_{\text {th }}}\left\{\beta^{-}\right.$Fig. 8 Nuclide Mass Region 133-137 


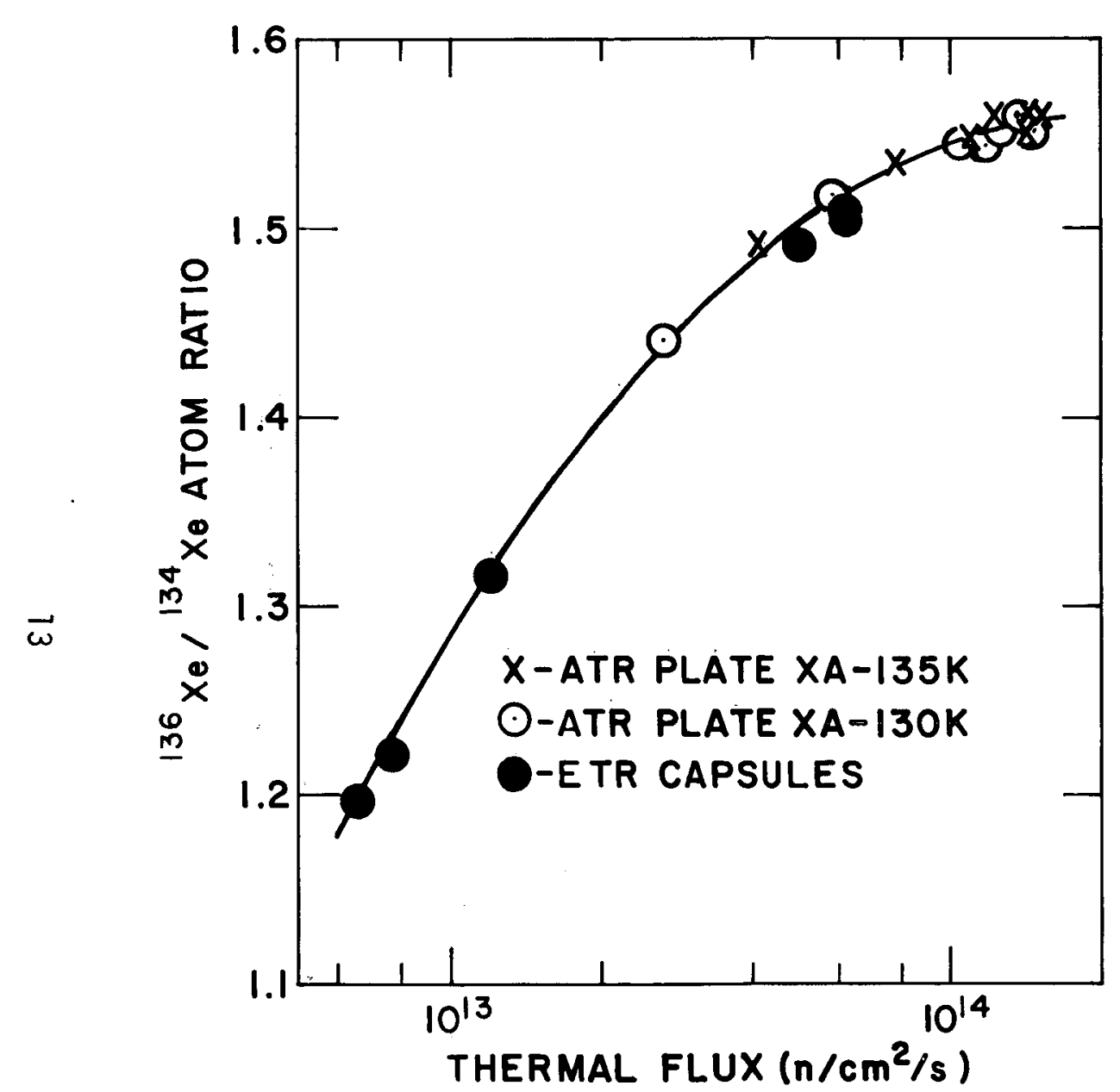

Fig. 9 Correlation of ${ }^{136} \mathrm{Xe} /{ }^{134} \mathrm{Xe}$ Atom Ratio with Neutron Flux

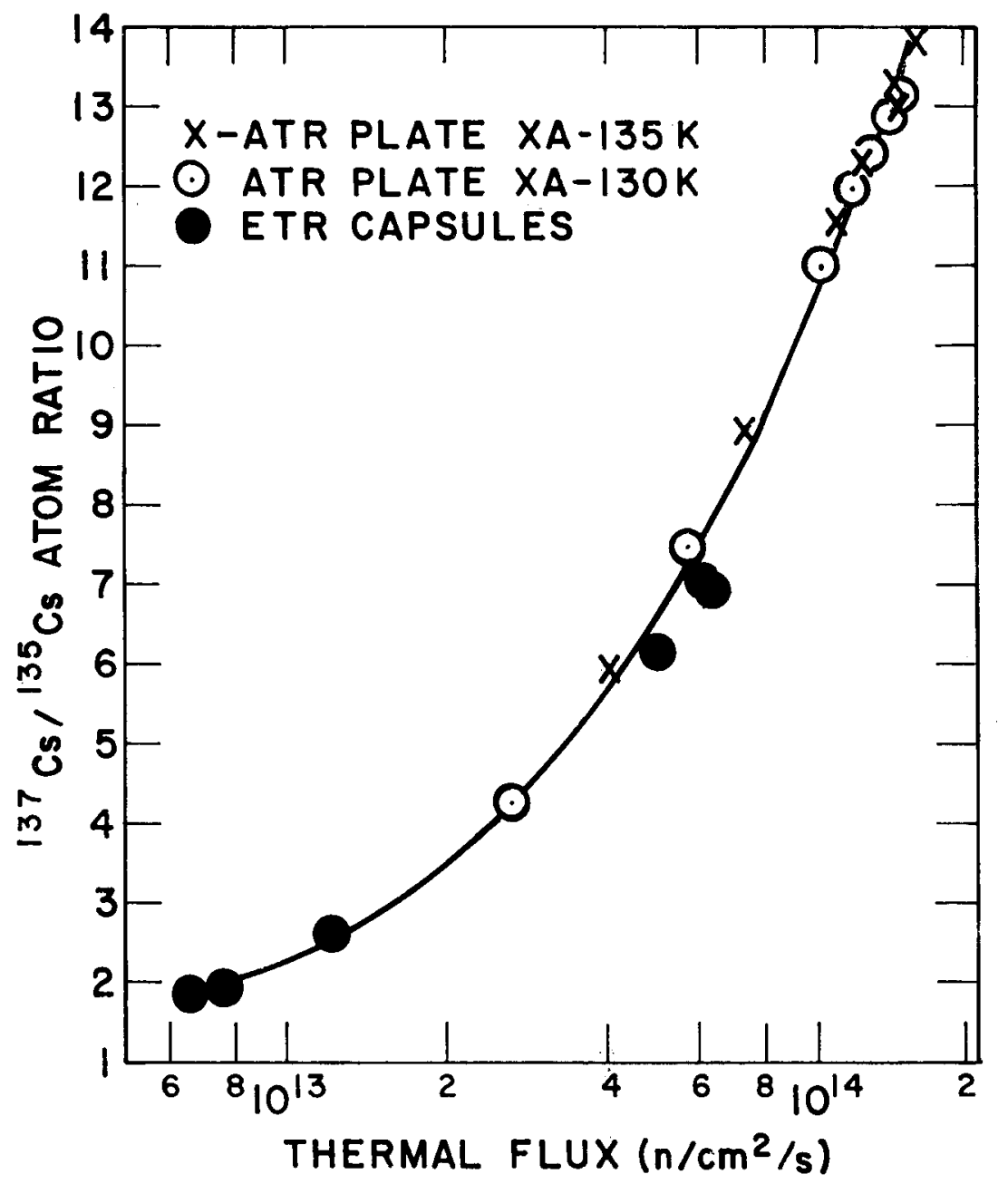

Fig. 10 Correlation of $1^{37} \mathrm{Cs} / 1^{35} \mathrm{Cs}$ Atom Ratio with Neutron Flux 
of the two ratios, ${ }^{136} \mathrm{Xe} /{ }^{134} \mathrm{Xe}$ and ${ }^{137} \mathrm{Cs} /{ }^{135} \mathrm{Cs}$, which can be correlated with neutron flux, the most sensitive, by far, is ${ }^{137} \mathrm{Cs} /{ }^{135} \mathrm{Cs}$. Over the flux range of $1 \times 10^{13}-1 \times 10^{14} \mathrm{n} / \mathrm{cm}^{2} / \mathrm{s}$, the ${ }^{137} \mathrm{Cs} /{ }^{135} \mathrm{Cs}$ ratio changes by a factor of $\sim 5$, while the ${ }^{136} \mathrm{Xe} /{ }^{134} \mathrm{Xe}$ ratio only changes $220 \%$. The correlation of $136 \mathrm{Xe} /{ }^{134} \mathrm{Xe}$ with neutron flux is shown in Figure 9, and that for ${ }^{137} \mathrm{Cs} /{ }^{135} \mathrm{Cs}$ in Figure 10.

Another ratio which can be correlated with neutron flux is ${ }^{148} \mathrm{Nd} / 145+146 \mathrm{Nd}$, al though it is not as sensitive as those involving $135 \mathrm{Xe}$. In this case, $11 \mathrm{~d}-147 \mathrm{Nd}$ with a capture cross section of $2440 \mathrm{~b}$ is transmuted to ${ }^{148} \mathrm{Nd}$ while the sum of ${ }^{145} \mathrm{Nd}+146 \mathrm{Nd}$ is constant. This correlation is most sensitive at high neutron fluxes $\left(>10^{14} \mathrm{n} / \mathrm{cm}^{2} / \mathrm{s}\right)$. The correlation with neutron flux is shown in Figure 11 . This shows why caution must be exercised in the use of $148 \mathrm{Nd}$ as a monitor for the number of fissions and a/oF.

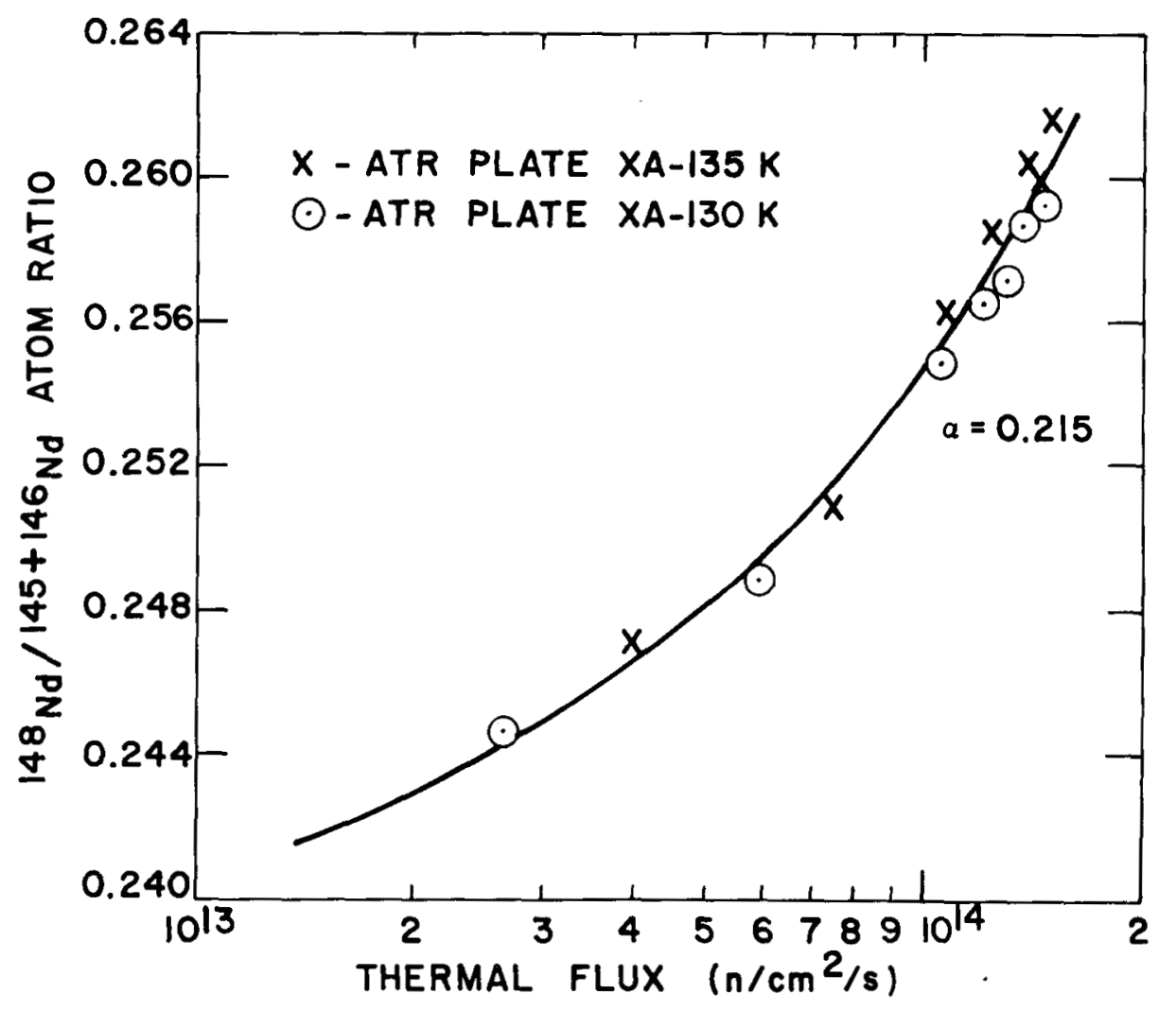

ACC-A-3152

Fig. 11 Correlation of $148 \mathrm{Nd} / 145+146 \mathrm{Nd}$ Atom Ratio with Neutron Flux 
One important item relative to the use of any isotope ratio to deduce neutron flux is the half-life of the capturing nuclide compared to the up and down time of the reactor. For $9.17 \mathrm{~h}-135 \mathrm{Xe}$, the problem is negligible; however, for the case of $11 \mathrm{~d}-147 \mathrm{Nd}$, short operating cycles and a long down time relative to 11 days could seriously affect the usefulness of the ${ }^{148} \mathrm{Nd} /{ }^{145^{+}} 146 \mathrm{Nd}$ correlation with neutron flux.

\section{HEAVY ELEMENT CORRELATIONS}

The quantity of plutonium produced in highly enriched $235 \mathrm{U}$ fuel is considerably less than in low enrichment power reactor fuels. For a first estimate, the production of plutonium can be considered to be proportional to the amount of $238 \mathrm{U}$ in the fuel, provided the neutron spectra are comparable. For most low enrichment power fuels, the $238 \mathrm{U}$ concentration of the fuel varies from $295-98 \%$, while in highly enriched fuels only $\sim 6 \%$ of the uranium is $238 \mathrm{U}$.

One unique feature relative to the production of plutonium in highly enriched $235 \mathrm{U}$ fuels is the isotopic abundance of ${ }^{238} \mathrm{Pu}$. For high a/oF $(>40 \%), 238 \mathrm{Pu}$ can be the second most abundant isotope following ${ }^{239} \mathrm{Pu}$. In Figure 12, we show the isotopic abundance of the plutonium isotopes as a function of a/oF for the ATR fuel plate samples. The high abundance of ${ }^{238} \mathrm{Pu}$ results primarily from neutron capture on $235 \mathrm{U}, 236 \mathrm{U}$, and $237 \mathrm{~Np}$. Because of the mode of production of $238 \mathrm{Pu}$, the amount of ${ }^{238} \mathrm{Pu}$ produced is very sensitive to the neutron spectrum and hence, $\alpha_{235}$. At low a/oF, there is also a dependency on the initial amount of $236 \mathrm{U}$ in the fuel. Another factor which can affect the production of ${ }^{238} \mathrm{Pu}$ is the flux level. This dependency results from the $6.75 \mathrm{~d}$ half-1ife of $237 \mathrm{U}$ and its $400 \mathrm{~b}$ thermal neutron capture cross section. Thus, with increasing flux levels, the amount of $6.75 \mathrm{~d}-237 \mathrm{U}$ decaying to ${ }^{237} \mathrm{~Np}$ is less because a larger fraction is transmuted to $238 \mathrm{U}$. The correlation of a/o $238 \mathrm{Pu}$ with $\mathrm{a} / \mathrm{o} 236 \mathrm{U}$ for the ATR fuel samples is shown in Figure 13.

The measured total plutonium/uranium ratio as a function of a/o $236 \mathrm{U}$ for the ATR fuel plate samples is shown in Figure 14. Also shown is the calculated ratio for two different values of $\alpha_{235}$. From these data, it is quite evident that the production of plutonium in highly enriched $235 \mathrm{U}$ fuel is very dependent on the neutron spectrum. 


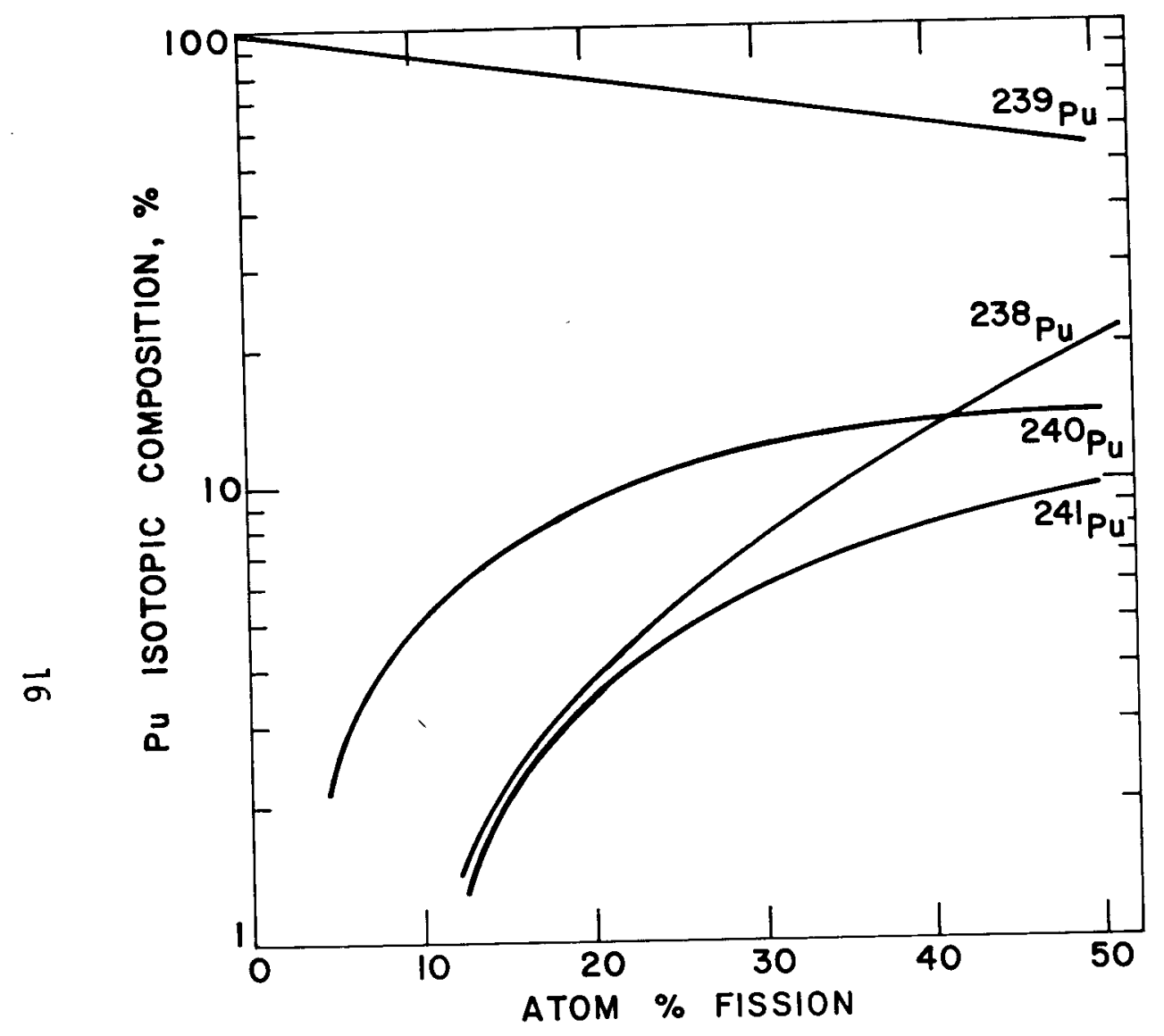

ACC $-\mathrm{A}-3147$

Fig. 12 Isotopic Composition of Plutonium Produced in the Irradiation of $95 \%$ Enriched $235 \mathrm{U}$

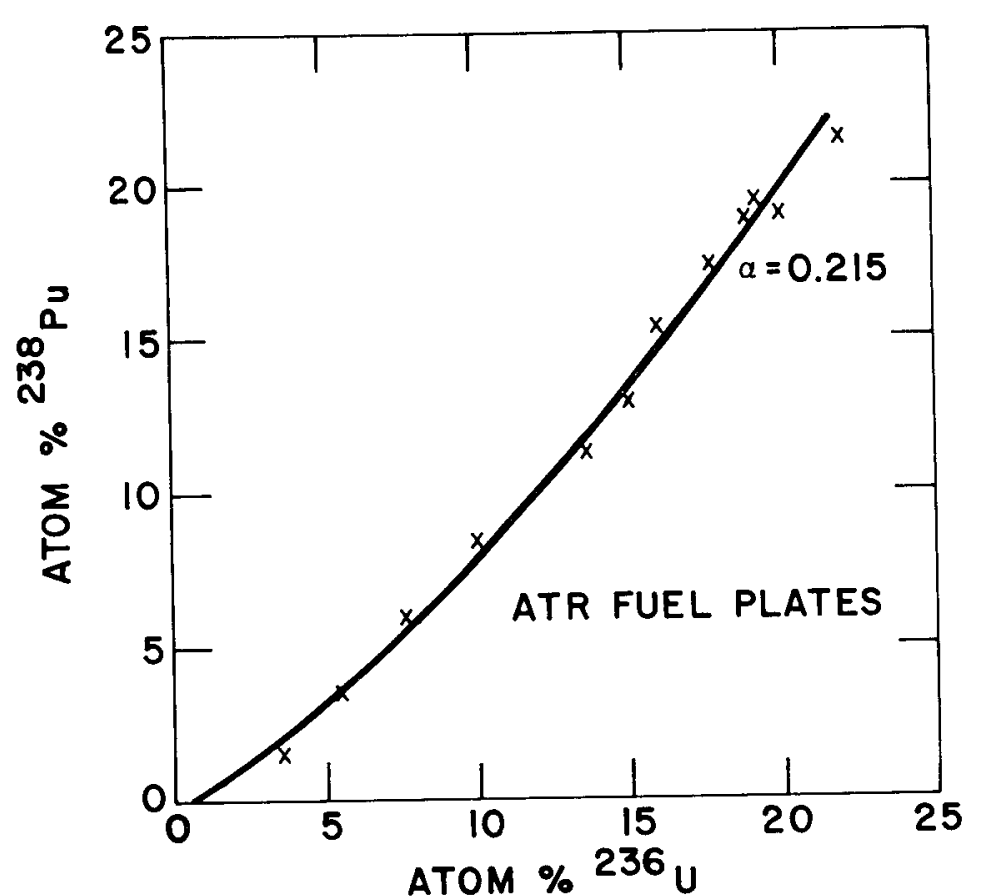

ACC-A-3149

Fig. 13 Correlation of a/o 238pu with a/o $236 \mathrm{U}$ 
To date we have not examined all possible heavy element correlations for highly enriched $235 \mathrm{U}$ fuel; however, based on the 1 imited amount of study which has been done, it is apparent that the bulk of the possible heavy element correlations may not be too useful because of the large neutron energy and $\alpha_{235}$ dependencies. Additional data are required to better evaluate the heavy element correlations.

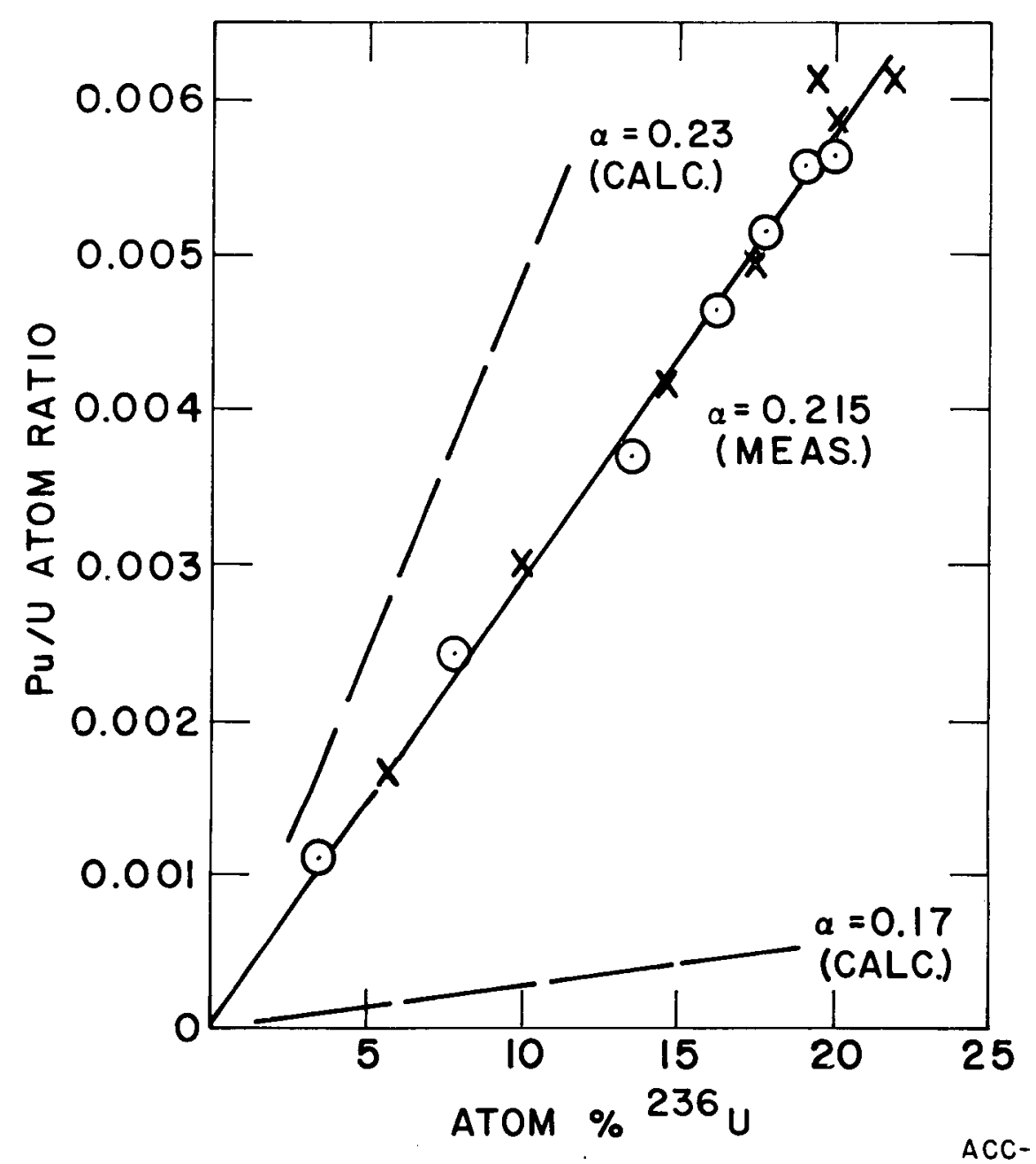

Fig. 14 Correlation of Pu/U Atom Ratio with a/o $236 \mathrm{U}$ 


\section{SUMMARY AND CONCLUSIONS}

Several correlations of fission product isotopic ratios with a/oF and neutron flux, for highly enriched $235 \mathrm{U}$ fuel irradiated in two dif-. ferent water moderated thermal reactors, have been evaluated. In general, excellent correlations were indicated for samples irradiated in the same neutron spectrum; however, significant differences in the correlations were noted with the change in neutron spectrum. Table II lists the correlations evaluated, and notes the usefulness of the various isotope ratios for isotope correlation studies.

For highly enriched $235 \mathrm{U}$ fuel, the most useful correlation involves the ratios of the neodymium isotopes. The correlation of the isotopic ratio $143 \mathrm{Nd} / 145^{+146} \mathrm{Nd}$ with a/oF has wide applicability and appears insensitive to the neutron spectrum. The ${ }^{146} \mathrm{Nd} /{ }^{145} \mathrm{Nd}$ isotope ratio can be used in conjunction with the $143 \mathrm{Nd} / 145+146 \mathrm{Nd}$ isotope ratio to give an estimate of the neutron spectrum in which the fuel was irradiated. The ${ }^{137} \mathrm{Cs} /{ }^{135} \mathrm{Cs}$ atom ratio shows promise for a correlation with neutron flux.

Correlations involving heavy element ratios are very sensitive to the neutron spectrum. 


\section{TABLE II. SUMMARY OF ISOTOPE CORRELATIONS FOR HIGHLY ENRICHED $235 \mathrm{U}$ FUEL}

\begin{tabular}{|c|c|c|}
\hline $\begin{array}{l}\text { Fission Product } \\
\text { Isotope Ratio }\end{array}$ & $\begin{array}{l}\text { Correlation } \\
\text { Information }\end{array}$ & Remarks \\
\hline${ }^{84} \mathrm{Kr} /{ }^{83} \mathrm{Kr}$ & $\mathrm{a} / \mathrm{oF}$ & $\begin{array}{l}\text { Slight sensitivity to neutron } \\
\text { spectrum }\end{array}$ \\
\hline${ }^{132} \mathrm{Xe} /{ }^{131} \mathrm{Xe}$ & $\mathrm{a} / \mathrm{oF}$ & $\begin{array}{l}\text { High sensitivity to neutron } \\
\text { spectrum }\end{array}$ \\
\hline${ }^{134} \mathrm{Cs} /{ }^{133} \mathrm{Cs}$ & $\mathrm{a} / \mathrm{oF}$ & $\begin{array}{l}\text { High sensitivity to neutron } \\
\text { spectrum }\end{array}$ \\
\hline${ }^{134} \mathrm{Cs} /{ }^{137} \mathrm{Cs}$ & $\mathrm{a} / \mathrm{oF}$ & $\begin{array}{l}\text { High sensitivity to neutron } \\
\text { spectrum }\end{array}$ \\
\hline $143 \mathrm{Nd} / 145+146 \mathrm{Nd}$ & $\mathrm{a} / \mathrm{oF}$ & $\begin{array}{l}\text { Wide applicability - insensitive } \\
\text { to neutron spectrum }\end{array}$ \\
\hline${ }^{146} \mathrm{Nd} /{ }^{145} \mathrm{Nd}$ & $\mathrm{a} / \mathrm{oF}$ & $\begin{array}{l}\text { High sensitivity to neutron } \\
\text { spectrum }\end{array}$ \\
\hline${ }^{136} \mathrm{Xe} /{ }^{134} \mathrm{Xe}$ & $n-f 7 u x$ & $\begin{array}{l}\text { Useful correlation for esti- } \\
\text { mating neutron flux. More } \\
\text { sensitive at low flux levels } \\
\left(<10^{13} \mathrm{n} / \mathrm{cm}^{2} / \mathrm{s}\right) \text {. No serious } \\
\text { spectrum effects. }\end{array}$ \\
\hline${ }^{135} \mathrm{Cs} /{ }^{137} \mathrm{Cs}$ & $n-f l u x$ & $\begin{array}{l}\text { Useful correlation for esti- } \\
\text { mating neutron flux. More } \\
\text { sensitive than } 136 \mathrm{Xe} / 134 \mathrm{Xe} \\
\text { ratio. Most sensitive for } \\
\text { neutron fluxes in excess of } \\
1 \times 10^{13} \mathrm{n} / \mathrm{cm}^{2} / \mathrm{s} \text {. No serious } \\
\text { spectrum effects. }\end{array}$ \\
\hline $148 \mathrm{Nd} / 145+146 \mathrm{Nd}$ & $n-f l u x$ & $\begin{array}{l}\text { Less useful correlation than } \\
\text { those involving } 135 \text { Xe. Subject } \\
\text { to error when long reactor down } \\
\text { times involved. }\end{array}$ \\
\hline $146 \mathrm{Nd} /{ }^{145} \mathrm{Nd}$ & n-spectrum & $\begin{array}{l}\text { Useful for estimating } \alpha_{23} \text { when } \\
\text { combined with } 143 \mathrm{Nd} / 145+146 \mathrm{Nd} \text {. }\end{array}$ \\
\hline \multicolumn{2}{|c|}{ HEAVY ELEMENT CORRELATIONS } & $\begin{array}{l}\text { Very sensitive to neutron } \\
\text { spectrum. }\end{array}$ \\
\hline
\end{tabular}

Correlation

armation

Slight sensitivity to neutron spectrum

spectrum

High sensitivity to neutron spectrum

Wide applicability - insensitive High sensitivity to neutron spectrum mating neutron flux. More sensitive at low flux levels $\left(<10^{13} \mathrm{n} / \mathrm{cm}^{2} / \mathrm{s}\right)$. No serious spectrum effects. mating neutron flux. More sensitive than ${ }^{136} \mathrm{Xe} /{ }^{134} \mathrm{Xe}$ ratio. Most sensitive for neutron fluxes in excess of $1 \times 10^{13} \mathrm{n} / \mathrm{cm}^{2} / \mathrm{s}$. No serious Less useful correlation than those involving ${ }^{135} \mathrm{Xe}$. Subject to error when long reactor down times involved.

Useful for estimating $\alpha_{23}$ when
combined with $143 \mathrm{Nd} / 145+146 \mathrm{Nd}$. spectrum. 


\section{REFERENCES}

1. W. J. Maeck, "Proposed Determination of Nuclear Fuel Burnup Based on the Ratio of Two Stable Fission Products of the Same Element", Phillips Petroleum Co. - Atomic Energy Division Report IDO-14642 (1965).

2. R. Berg, C. Foggi, L. Koch, R. Kraemer, F. J. Woodman, "Value and Use of Isotopic Correlations in Irradiated Fuels", Proceedings of a Symposium, Practical Applications of R\&D in the Field of Safeguards, by the European Safeguards Research and Development Association, Rome (March 7-8, 1974).

3. S. F. Mughabghab, D. I. Garber, "Neutron Cross Sections, Resonance Parameters", National Neutron Cross Section Center, Brookhaven National Laboratory, BNL 325, Vo1. 1, 3rd Ed. (1973).

4. L. Koch, M. Bresesti, "Improved Method for the Verification of Reprocessing Input Analysis", Nucl. Mat. Mgmt. Vol. IV, No. 3 (1975).

5. A. Ariemma, et al, "Experimental and Theoretical Determination of Burnup and Heavy Isotope Content in a Fuel Assembly Irradiated in the Garigliano Boiling Water Reactor", EUR 4638 (1971).

6. A. Buono, et al "Isotope Correlations in the Data Obtained from Irradiated Fuels of ENEL's Nuclear Power Stations", IAEA Working Group in the Use of Isotopic Composition Data in Safeguards, Vienna (April 1972).

7. R. Bannella, et al, "Relative Measurement of Burnup and Plutonium Content in PWR Assemblies, International Meeting of ANS, (November 1972).

8. W. J. Maeck, "A Review of Fission Product Nuclear Data Requirements for Investigation of Irradiated Nuclear Fuel", Review Paper No. 6 Second IAEA Advisory Group Meeting on Fission Product Nuclear Data, Petten, Netherlands (September 1977). 
DISTRIBUTION RECORD FOR ICP- 1156

Internal Distribution

1 - Chicago Patent Group - DOE 9800 South Cass

Argonne, IL 60439

1 - C. A. Benson

Idaho Operations Office - DOE

Idaho Falls, ID 83401

1 - H. P. Pearson

Information Management - EG\&G

10 - INEL Technical Library

20 - Author

40 - Special Internal

\section{External Distribution}

389 - Distribution Under UC-4, UC-15 - Chemistry, Safeguards--Nuclear Materials Security

Total Copies Printed: 462 